\section{Czy ruscy chłopi mogą być sexy? O urządzeniu seksualności w Galicji}

Katarzyna Glinianowicz
Artykuł powstał w ramach projektu badawczego nr 2016/20/S/HS2/00584 finansowanego ze środków Narodowego Centrum Nauki.

TEKSTY DRUGIE 2021, NR 3, S. 201-217

DOI: 10.18318/td.2021.3.14 | ORCID: 0000-0001-8959-6047

Genealogia jako analiza pochodzenia zwraca się więc ku miejscu, w którym krzyżują się ciało i historia. Musi pokazywać ciało do cna napiętnowane historią i historię rujnującą ciało.

M. Foucault Nietzsche, genealogia, historia

\section{Ruska elita niewcielona}

Od kilkunastu lat literaturoznawstwo polskie eksploruje kluczem postkolonialnym narracyjne reprezentacje stosunków polsko-ruskich/ukraińskich' ${ }^{1}$.W wielowątkowych badaniach brak jednak perspektywy, która w duchu

1 Por. Studia postkolonialne w Polsce. Wybrana bibliografia, zestawiła E. Domańska, w: L. Gandhi Teoria postkolonialna. Wprowadzenie krytyczne, przeł. J. Serwański, posł. E. Domańska, Wydawnictwo Poznańskie, Poznań 2008, s. 179-187; B. Bakuła Studia postkolonialne w Europie Środkowej oraz Wschodniej 1989-2009. Kwerenda wybranych problemów w ramach projektu badawczego, w: Kultura po przejściach, osoby z przeszłością. Polski dyskurs postzależnościowy - konteksty i perspektywy badawcze, red. R. Nycz, Universitas, Kraków 2011, s. 137-165.

\section{Katarzyna}

Glinianowicz -

doktorka, adiunktka

w Instytucie

Slawistyki Polskiej

Akademii Nauk. Bada literatury galicyjskie w ujęciu studiów postkolonialnych i antropologii cielesności. Pracuje nad projektem dotyczącym seksualności w literaturach Galicji. Autorka monografii Z cienia polskości. Ukraińska proza galicyjska przełomu XIXiXXwieku. Kontakt: katarzyna. glinianowicz@ispan. waw.pl. 
studiów nad subalternami problematyzowałyby dostęp do podmiotowości podporządkowanego chłopstwa prawosławnego/greckokatolickiego ${ }^{2}$. Wynika to z założeń badaczy, którzy nie dostrzegają ich podwójnej zależności: od elit ruskich/ukraińskich i polskich. Odtwarzają natomiast ramy interpretacyjne konceptu esencjalnej polskiej tożsamości szlacheckiej ${ }^{3}$ konstruowanej w opozycji do chłopstwa ruskiego, i tym samym pomijają wątki społecznych różnic, podziałów, pęknięć wewnątrz grup podporządkowanych. Nawet nurt krytyczny analizy polskich reprezentacji autochtonicznych mieszkanek i mieszkańców „kresów” pomija elity ruskie/ukraińskie ${ }^{4}$ w postaci chociażby wywodzących się ze starszyzny kozackiej dworian na ziemiach ukraińskich w Imperium Rosyjskim i duchowieństwa greckokatolickiego w Galicji austriackiej. Elity te istniały, wprawdzie pod berłem carskim i cesarskim, niemniej partycypowały we władzy oraz tworzyły swój dyskurs (w tym literacki).

2 Por. Chłopska (nie)pamięć. Dziedzictwo chłopskości w polskiej literaturze i kulturze, red. G. Grochowski, D. Krawczyńska, G. Wołowiec, Universitas, Kraków 2019 oraz poświęcone chłopskości "Teksty Drugie" (2017 nr 6).

3 Podobne ujęcia krytykowały m.in.: K. Chmielewska Tak i nie. Meandry polskiego dyskursu postkolonialnego i postzależnościowego, w: (P)o zaborach, (p)owojnie, (p)o PRL. Polski dyskurs postzależnościowy dawniej i dziś, red. H. Gosk, E. Kraskowska, Universitas, Kraków 2013, s. 559-574; M. Golinczak Postkolonializm: przed użyciem wstrzq̨snąć!, „Recykling Idei” 2008 nr 10, s. 108-113; G. Borkowska Perspektywa postkolonialna na gruncie polskim - pytania sceptyka, w: Kultura po przejściach, s. 167-180; D. Kołodziejczyk Postkolonialny transfer na EuropęŚrodkowo-Wschodniq, W: tamże, s. 117-136.

4 Takie pominięcie stało się np. przyczyną zredukowania przez Hannę Gosk Ukraińców i Białorusinów do "ludu" niewytwarzającego dyskursu o przynależności do ziemi wołyńskiej lub mińskiej: „Można by zauważyć, iż ani Ukraińcy, ani Białorusini nie manifestowali w owym czasie swego prawa do Wołynia czy Mińszczyzny [...]. Lud ukraiński czy białoruski nie tworzył w interesujących mnie tutaj trzech pierwszych dekadach XX wieku dyskursu (także literackiego), który legitymizowałby jego przynależność do ziemi, ale też poza wszystkim innym warto zauważyć, iż raczej nie dowodzi się czegoś, co uważa się za naturalne" (H. Gosk Opowieści „skolonizowanego/kolonizatora". W kręgu studiów postzależnościowych nad literaturą polską XX i XXI wieku, Universitas, Kraków 2010, s. 67). Na tę konstatację można odpowiedzieć fragmentem wiersza Ziemia (1906) autorstwa klasyka literatury białoruskiej rodem z Mińszczyzny Janka Kupały (1882-1942): „Ziemio, miłuję cię wiernie i stale / Przylgnę do ciebie, jak do kochanki” (я. Купала Зямля, w: Беларуская палічка, https://knihi.com/Janka_Kupala/Ziamla.html, 2.08.2019) lub słowami jednego z wielu wywodzących się z Wołynia pisarzy ukraińskich - Ułasa Samczuka (1905-1987), autora m.in. trylogii Wołyń (Волинь, 1932-1937): „Chcę być kronikarzem przestrzeni ukraińskiej w czasach, które widzę, słyszę, przeżywam" (У. Самчук Від автора, w: tegoż Юність Василя Шеремети, Прометей, Мюнхен 1946, s. 5). Jeśli nie zaznaczam inaczej, tłumaczenia są mojego autorstwa - K.G. 
Dostrzeżenie ruskich elit kompradorskich pozwala stwierdzić, że szlachcic polski miał na "kresach” konkurenta, wykrawającego dla siebie, jak powiedziałaby Gayatri Chakravorty Spivak ${ }^{5}$, porcje hegemonicznych tortów serwowanych przez imperia Habsburgów i Romanowów. Dzięki usytuowaniu w społeczno-kulturowych instytucjach władzy reprodukowały one wiedzę o sobie i „swym” chłopstwie, kontestującą i w miarę możliwości negującą władzę/wiedzę szlachty polskiej oraz obydwu imperiów. Na przykład Jan Sowa w Fantomowym ciele króla, popełniając błąd metodologiczny, określił mianem subalternów Kozaków, czyli tych, którzy wcale nie byli najniższą warstwą podporządkowanego społeczeństwa ruskiego. Wbrew temu, co twierdzi Sowa ${ }^{6}$, Kozaczyzna - mimo prób jej wykluczania z dyskursu władzy przez szlachtę polską - negocjowała swój udział w strukturach hegemonicznych Rzeczypospolitej i sama wyrażała własną podmiotowość.

Wady polskich ujęć relacji polsko-ukraińskich są odpowiednikiem zdemaskowanej przez Spivak postawy badawczej intelektualistów zachodnich opisujących podporządkowanych innych za pomocą hegemonicznego systemu reprezentacji. Zdaniem badaczki postawa ta służy „utrwaleniu podmiotu Zachodu czy też Zachodu jako Podmiotu"' przez umacnianie subalternów jako przedmiotu analizy. Na gruncie badań polskich szlachecki Podmiot jest utrwalany dzięki reprodukcji przedmiotu refleksji naukowej w postaci ruskiej subalterności. Dotychczasowe inspiracje postkolonialne są podporządkowane kolonialnemu spojrzeniu szlachcica na wyłącznie chłopskich Rusinów, jakkolwiek nie ulega wątpliwości, że Bohdan Chmielnicki et consortes subalternami być nie mogli.

W powyższym kontekście zajmę się literackimi reprezentacjami chłopów w tekstach przedstawicieli elit ruskich/ukraińskich w Galicji. Skupię się na wybranych utworach i motywach, które stanowią część o wiele obszerniejszego korpusu literatury ruskiej/ukraińskiej podejmującej interesujący mnie temat. Skoncentruję się na narracjach powstałych od nadania praw wyborczych chłopom w 1861 roku do końca lat 8o. XIX wieku, gdy po rozprawie

5 L. de Kock An interview with Gayatri Chakravorty Spivak, "ARIEL: A Review of International English Literature" 1992 no. 3, s. 45-46.

6 Według Sowy "Kozacy byli więc subalterns ze względu na niemożliwość wypowiedzenia się, która uniemożliwiała im również nazywanie się w określony sposób [...]" (J. Sowa Fantomowe ciało króla. Peryferyjne zmagania z nowoczesną formą, Universitas, Kraków 2011, s. 451).

7 G. Chakravorty Spivak Czy podporzq̨dkowani inni moga przemówić?, przeł. E. Majewska, „Krytyka Polityczna" 2010 nr 24/25, s. 196. 
sądowej nad rusofilami w 1882 roku $^{8}$ trajektoria ruchu ruskiego zmienia się na korzyść ukrainofilów. Następne etapy ruchu ruskiego/ukraińskiego wymagają szerszego namysłu, wychodzącego poza ramy artykułu, podobnie jak odrębnych badań domagają się inne konteksty galicyjskiej subalterności, np. genderowej.

Tytułowe pytanie „Czy ruscy chłopi mogą być sexy?” (prócz tego, że jest aluzją do Can the subaltern speak? Spivak) wskazuje na seksualność jako punkt wyjścia badań nad sposobami kształtowania podmiotowości chłopstwa w ramach konstruowanej przez elity wspólnoty ruskiej/ukraińskiej. Przyglądam się zatem sprzężeniu emancypowania (się) chłopów z włączaniem ich jako świadomego bytu seksualnego do społeczeństwa i narodu. Świadomy byt seksualny - za Foucaultowską genealogią seksualności - rozumiem jako efekt procesu stawania się podmiotem pragnienia zdolnym do ujarzmiania seksualności, czyli przyswajania norm kulturowych, które tę seksualność nadzorują. Ujarzmianie konstytuuje bowiem ów byt - podmiot wiedzy/ władzy9 . Precyzując, badam literacki dyskurs seksualności 1) obejmujący początkowo przedstawicieli ruskiej elity duchownej, 2) następnie, w ramach przemian społeczno-politycznych, włączający w swe pole ruskiego chłopa, 3) który - przyswoiwszy ten dyskurs w warunkach swej transformacji społecznej - przestaje być chłopem, 4) jako aktywy podmiot społeczny partycypuje w ruskiej/ukraińskiej władzy 5) i w jej ramach formuje kontrwiedzę o ukraińskiej seksualności.

\section{Venerei Rutheni, frigidi Poloni}

Zdaniem Michela Foucaulta seksualność to „szczególnie intensywne miejsce zbieżności relacji władzy"10. Podążając tym tropem, przyjmuję seksualność chłopstwa ruskiego jako punkt węzłowy galicyjskiej przestrzeni społeczno-kulturowej. Jej ruscy uczestnicy wytyczali normy seksualne, tożsamościowe

8 Na ławie oskarżonych zasiedli czołowi przedstawiciele rusofilstwa, podejrzani m.in. o szpiegostwo na rzecz Imperium Rosyjskiego. Punktem zapalnym była konwersja we wsi Hniliczki, gdzie chłopi pod namową ks. Iwana Naumowycza zmienili konfesję z greckokatolickiej na prawosławną (por. A.В. Вендланд Русофіли Галичини. Українські консерватори між Австрією ma Росією, 1848-1915, пер. Х. Назаркевич, Літопис, Львів 2015, s. 221-261). Warszawa 1995, passim; tegoż Nadzorować i karać. Narodziny więzienia, przeł. T. Komendant, Aletheia, Warszawa 1998, s. 191-220. 
i polityczne w ramach kilku płynnych frakcji składających się głównie z duchowieństwa greckokatolickiego: polonofilów (tak zwani gente Rutheni, natione Poloni), starorusinów i jego odłamu rusofilskiego oraz ukrainofilów ${ }^{11}$. Do Wiosny Ludów wśród elity ruskiej dominowali polonofile i starorusini. Po 1848 roku większe poparcie zyskała frakcja staroruska. W latach 6o. w monarchii Habsburgów zapoczątkowano demokratyczne reformy, co wiązało się z nadaniem Galicji w 1867 roku autonomii i przekazaniem przez Wiedeń zarządu nią szlachcie polskiej. Elita staroruska stanęła wtedy przed podwójnym wyzwaniem: z jednej strony musiała skonfrontować swój konserwatyzm z modernizacją, z drugiej - bronić siebie i „swoich" chłopów przed polonizacją i latynizacją ze strony szlachty polskiej i kleru rzymskokatolickiego.

Starorusini swój fundament społeczno-kulturowy postrzegali w Cerkwi greckokatolickiej. Instytucja ta stanowiła zatem część ruskiego urządzenia seksualności ${ }^{12}$ : chrześcijańskie zasady moralne, obyczajowość plebanii i cerkiewne prawo kanoniczne wpływały na ich wyobrażenia i praktyki

11 Polonofile uważali, że w sferze kultury i polityki Rusini galicyjscy powinni pozostać częścią społeczności polskiej. Starorusinów, ruso- i ukrainofilów „łączyła” podstawowa kwestia: wiedzieli, że nie są Polakami. Różnica natomiast dotyczyła samookreślenia, które w pierwszej kolejności wiązało się z ustaleniem, do jakiej wspólnoty chcą należeć Rusini habsburscy. Starorusini byli lokalnymi patriotami ruskimi, lojalnymi wobec Wiednia, ich zdaniem Rusini galicyjscy stanowili 3-milionową społeczność tylko w obrębie Cesarstwa Austrii. Rusofile i ukrainofile byli przekonani, że greckokatoliccy Rusini znad Dniestru i prawosławni Małorusini znad Dniepru są częścią tego samego narodu. Różnica polegała na tym, że ukrainofile jako naród rozumieli 10-milionową wspólnotę ukraińską zamieszkującą tereny od Karpat po Kubań, a rusofile 6o-milionową religijno-kulturową wspólnotę Słowian wschodnich od Karpat po Ocean Spokojny. Autoprezentacja ta wynikała z ich koncepcji ruskich/russkich dziejów, zgodnie z którą centrum polityczno-kulturowe Rusi przemieszczało się z Kijowa do Włodzimierza nad Klaźmą, następnie do Moskwy i w końcu do Sankt Petersburga. Wynikało z niej, że schedę po Rusi Kijowskiej przejęło Imperium Rosyjskie. Tymczasem ukrainofile za spadkobierców średniowiecznej Rusi uważali tylko Księstwo Halicko-Wołyńskie, a następnie państwo kozackie, zatem ciągłość historyczną konstytuowały nie ruskie/russkie centra państwowe, lecz kolektywny "duch" ludu ruskiego/ ukraińskiego, jego język i folklor (por. m.in. P.R. Magocsi Historia Ukrainy. Ziemia i ludzie, przeł. M. Król, A. Waligóra-Zblewska, Księgarnia Akademicka, Kraków 2017, s. 595-626; F. Świstun Spory austryackich Rusinów o kwestyę narodowości, „Świat Słowiański” 1910 nr 71, s. 250-276; О. Аркуша, М. Мудрий Русофільство в Галичині в середині XIX - на початку XX cm.: генеза, етапи розвитку, світогляд, „Вісник Львівського університету. Серія історична” 1999 № 34, S. 231-268). stwie władzy i wiedzy o seksualności, czyli tworzenia sieci relacji między wiedzą i praktyką seksualną a stosunkami politycznymi, religijnymi, ekonomicznymi, płciowymi etc. (M. Foucault Historia seksualności, s. 71-117). 
erotyczne, małżeńskie, rodzinne. Brak celibatu wśród duchowieństwa był nie tylko szczególnym świadectwem odrębności kultury ruskiej od polskiej, ale ustanawiał też wysoką pozycję wartości, takich jak ruska rodzina, moralność publiczna i osobista, życie dla wspólnoty, przeciwstawianych wartościom uznawanym za właściwe dla polskiej kultury rzymskokatolickiej, czyli amoralności, karierowiczostwu i egocentryzmowi ${ }^{13}$. Różnice aksjologiczne były ważkim argumentem uzasadniającym m.in. postulat podziału Galicji na ruską część wschodnią i zachodnią - polską, czego elita ruska od 1848 roku konsekwentnie domagała się od Wiednia.

Brak celibatu i konserwatyzm przyczyniły się do kultywowania stanowej endogamii wśród księży greckokatolickich, patriarchalnych „ojców narodu"14. Z tego względu poglądy starorusinów w kwestii utrzymania hierarchii społecznej nie odbiegały od stanowiska konserwatywnej szlachty polskiej ${ }^{15}$. Pomaga to zrozumieć, dlaczego akcje powieści pisarzy ruskich - pochodzącego z rodziny duchownego Fyłymona Kałytowskiego (1841-1912) i księdza Władymira (Wołodymyra) Chylaka (1843-1893) ${ }^{16}$ - toczą się w przeszłości pańszczyźnianej, w ramach której badają możliwość zmiany stosunków władzy: miejsce polskiej szlachty miałaby zająć ruska elita duchowna. Projektowi temu towarzyszy ujarzmienie ruskiej seksualności, którą zazwyczaj ucieleśnia

13 А. Заярнюк Соціальні аспекти статі в дискурсі греко-католицького духовенства Галичини другої половини ХІХ столітmя, „Україна Модерна” 2000 nr 4/5, s. 50-8о.

14 Nawiązuję do tytułu książki Bernadetty Wójtowicz-Huber "Ojcowie narodu”. Duchowieństwo greckokatolickie w ruchu narodowym Rusinów galicyjskich (1867-1918), Wydawnictwa UW, Warszawa 2008.

15 Nikołaj Czernyszewski (1828-1889), rosyjski filozof i socjaldemokrata; gdy na początku lat 60. XIX wieku analizował teksty publikowane na łamach wychodzącego we Lwowie opiniotwórczego czasopisma ruskiego "Słowo", doszedł do wniosku, że wśród galicyjskiej warstwy wysokiej jest wprawdzie niepomiernie mniej Rusinów niż Polaków, lecz ich stosunek do chłopów i ładu pańszczyźnianego niczym się nie różni od poglądów konserwatywnej szlachty, ponieważ pana polskiego i ruskiego łączą te same interesy ekonomiczne $($ Н. Чернышевский Национальная бестактность, w: Воспоминания о Тарасе Шевченко, сост. В.С. Бородин, Н.Н. Павлюк, предисл. В.Е. Шубравский, Днипро, Киев 1988, http://litopys.org.ua/shevchenko/vosp72. htm, 30.07.2019).

Spuścizna pisarzy starorusinów jest nieobecna w narodowych historiach literatur galicyjskich. Wyjątek stanowią ci, którzy pochodzili z rodów księżowskich Łemkowszczyzny i dziś są włączani do projektu kanonu karpatorusińskiego, o czym świadczy seria „Biblioteka Klasyki Łemkowskiej” („Бібліотека Лемківской Клясикы”) wydawana od 2011 roku przez stowarzyszenie "Ruska Bursa” w Gorlicach (por. H. Duć-Fajfer Literatura łemkowska w drugiej połowie XIX i na poczq̨tkuXX wieku, PAU, Kraków 2001). 
postać popadianki (córka księdza greckokatolickiego), a niekiedy również chłopki. Proces ten wyznacza normy seksualne, dbając zwłaszcza o jedno: zachowanie nieprzekraczalnego dystansu między ciałami popadianki/chłopki i szlachcica-Polaka, ponieważ energia erotyczna tego drugiego zagraża stabilności ruskich granic tożsamościowych.

Powyższy schemat, realizowany w powieściach Zamiana (Замьнъ, 1867) ${ }^{17}$ Kałytowskiego i Szubieniczne wzgórze (Шибеничный верхъ, 1877) ${ }^{18}$ Chylaka, nawiązuje do popularnego w europejskiej literaturze romantycznej motywu prześladowanej dziewicy ${ }^{19}$. W jego ruskiej odsłonie rolę libertyna napastującego cnotliwą Rusinkę odgrywa polski szlachcic - właściciel wsi pańszczyźnianej we Lwowskiem baron Bonaparte ${ }^{20}$ (Zamiana) i terroryzujący mieszkańców Łemkowszczyzny rotmistrz wojsk konfederacji barskiej Chyrzewski (Szubieniczne wzgórze). Ten powracający w literaturze ruskiej (potem ukraińskiej²) dramat ciała chłopki i popadianki służy jako metafora relacji społeczno-etnicznych w Galicji22 ${ }^{2}$, wyraża niezgodę elity ruskiej na podrzędność w stosunku do tych, którzy - przywołując słowa narratora Zamiany - mają „szlachectwo na papierze, ale w sercu nie są szlachetni ni na krztynę"23.

Ograniczona, sprowadzona do poziomu parafii władza księdza greckokatolickiego nie jest w stanie uchronić chłopki przed gwałtem szlachcica, rozpościera się natomiast nad jego córką. Popadianka, której „natura” zostaje okiełznana przez ratio ojca, jest potraktowana jako totem chroniący ruskość, ponadto w systemie patriarchalnym służy podbudowaniu osłabianego przez

17 Ф.И. Калитовский Замьнъ, „Галичанинъ. Науково-белетристичная прилога до “Слова»” 1867 № 9-19.

І. Анонимъ [В. Хиляк] Шибеничный верхъ, w: tegoż Повьсти и разсказы, т. 1, Типографія Ставропигійскаго Института, Львовъ 1882.

19 M. PrazZmysły, śmierć i diabełw literaturze romantycznej, przeł. K. Żaboklicki, słowo/obraz terytoria, Gdańsk 2010, s. 99-162. Nazwisko bohatera demonstruje negatywny stosunek Kałytowskiego i galicyjskich rusofilów do polityki Napoleona I, przychylnej względem szlachty polskiej.

21 Motyw gwałtu szlachcica polskiego na Rusince jest obecny m.in. w powieściach Iwana Franki Filary społeczeństwa (Основи суспільности, 1894) і Wielki szuт (Великий шум, 1907). nej był również obecny w światowych narracjach antykolonialnych (por. A. Loomba Kolonializm/postkolonializm, przeł. N. Bloch, Wydawnictwo Poznańskie, Poznań 2011, s. 175).

23 Ф.И. Калитовский Замьнъ, „Галичанинъ. Науково-белетристичная прилога до “Слова»" 1867 № 11, s. 170. 
szlachtę autorytetu duchownego. Natomiast ciało i dusza chłopki to przestrzeń, którą literatura będzie dopiero odzyskiwać dla wspólnoty ruskiej, by na niej ustalić swą władzę kontrolującą granicę seksualną między swoim a obcym.

Redukcja postaci szlachciców do brutalnej seksualności staje się warunkiem koniecznym wynalezienia cnoty jako strategii budowania tożsamości Rusinów. Nadzorowana seksualność ruskiej kobiety gwarantuje oziębłość względem szlachcica transformowanego przez narrację w kulturowe „ciało obce”. Konsekwencją nadzoru staje się rozstanie z tymże „ciałem” i tożsamością typu gente Rutheni, natione Poloni oraz konstruowanie odrębnego ruskiego ja, inwestującego we własny kapitał moralny oraz kompensującego w ten sposób ograniczenia ekonomiczne i polityczne. Celem tej inwestycji jest zdobycie niepodzielnego prawa do „opieki” nad chłopstwem ergo ustanowienie własnej władzy nad Galicją Wschodnią.

\section{Przemiany intymności ruskich elit}

Elita staroruska była świadoma tego, że jeśli chce umacniać swoją pozycję„ojców narodu", musi nie tylko utrzymać kontrolę religijną nad parafianami, ale rozszerzać ją na pozostałe obszary życia społecznego, kulturowego i obyczajowego, by nie stracić swego taktycznego chłopskiego sojusznika, od którego głosu zaczynała być zależna. Habsburskie prawo wyborcze zaczęło bowiem obejmować chłopów, tworząc przestrzeń bliskości politycznej między elitą a ludem. Starorusini przystąpili do formowania sieci wiejskich komitetów wyborczych, by walczyć ze szlachtą o głosy chłopskie, co było równoznaczne z procesem sekularyzacji własnych kadr, zdolnych konkurować o władzę ${ }^{24}$. Decyzje te pociągały za sobą ważkie przemiany intymności ruskich elit ${ }^{25}$, w tym rozszczelnianie pilnie strzeżonych dotąd granic społecznych między „popem a chłopem”. Elita stanęła przed podstawowym dylematem: jak pokonać postpańszczyźnianą barierę społeczną i dopuścić chłopa do ich alkowy, małżeństwa, rodziny i w konsekwencji tego do sceny politycznej,

Por. A. Zayarnyuk Framing the Ukrainian Peasantry in Habsburg Galicia, 1846-1914, CIUS Press, Edmonton 2013, s. 169-176; А.В. Вендланд Русофіли Галичини, s. 265-287. łości, małżeństwie i seksie w kulturze Zachodu (A. Giddens Przemiany intymności. Seksualność, miłość i erotyzm we współczesnych społeczeństwach, przeł. A. Szulżycka, Wydawnictwo Naukowe PWN, Warszawa 2006). 
jednocześnie niczego nie tracąc z własnej pozycji, a wprost przeciwnie wzmacniając ją.

Literatura była częścią systemu, za pomocą którego elita wypróbowywała na sobie możliwe urządzenie seksualności ${ }^{26} \mathrm{w}$ warunkach kryzysu tradycyjnej rodziny księżowskiej spowodowanego modernizacją. Metaforą tego kryzysu w prozie Chylaka i Kałytowskiego jest obraz zdestabilizowanej przez dwór, niepełnej rodziny księżowskiej, z owdowiałym jegomościem lub imością (jak ze szlachecka nazywano w Galicji księżowskich współmałżonków) i półsierotą popadianką. Popadianka Ola z Chylakowego Szubienicznego wzgó$r z a$, która zgodnie z wolą dziadka, księdza Ioana, poślubia ruskiego chłopa Matwija i jednocześnie odrzuca umizgi polskiego szlachcica Chyżewskiego, wciela ideę zerwania solidarności klasowej skutkującej dotąd mariażami księżowsko-szlacheckimi. Wybór matrymonialny ojca Ioana symbolizuje przekraczanie dotychczasowej endogamii stanowej duchowieństwa greckokatolickiego wobec chłopstwa na rzecz konstruowania etnicznej wspólnoty ruskiej. Należy jednak podkreślić, że wybór ten nie pada na przeciętnego wiejskiego młodzieńca, lecz na syna wójta, który „posiada gospodarstwo niczym szlachcic"27. Ślub stanowi korzystną dla elity transakcję: popadianka Ola wkracza w związek małżeński wraz z kapitałem symbolicznym, chłop Matwij - z kapitałem materialnym.

Powyższe urządzenie seksualności przebiega na drodze negocjacji pomiędzy tradycjonalizmem a modernizacją, miłosne wzorce plebanii greckokatolickiej nie przystawały bowiem do pochodzenia społecznego wybranka. Chylak bez problemu przy użyciu repertuaru zaczerpniętego z powieści romansowych przedstawia zaloty szlachcica i rozterki zakochanej w nim popadianki, ale opis relacji między Olą a Matwijem jest schematyczny, skrótowy, pozbawiony romansowych środków retorycznych. Miłość tych dwojga nie dochodzi do głosu. Milczy także chłopski małżonek, pozostaje statystą w księżowskiej narracji patriarchalnej, umoralniającej Olę oraz ruskich czytelników - „ojców narodu” $\mathrm{i}$ ich córki - że od rzymskokatolickiego szlachcica lepszy bogaty greckokatolicki chłop. Ten rekompensuje niskie pochodzenie społeczne bazą ekonomiczną, która wraz z małżeństwem zostaje włączona

26 Foucault przypuszcza, „że urządzenie seksualności wcale nie zostało wprowadzone jako zasada ograniczająca przyjemność innych ludzi przez klasy tradycyjnie zwane «panującymi». Wygląda raczej na to, że ów system wypróbowały one najpierw na sobie" (M. Foucault Historia seksualności, s. 109). 
do pola wiedzy/władzy elity. Na tym kapitale tworzy ona ideologiczną nadbudowę w postaci księżowsko-chłopskiej wspólnoty ruskiej.

Piętnaście lat przed publikacją Szubienicznego wzgórza podobne problemy starał się rozwikłać przedstawiciel marginalnej wówczas opcji ukrainofilskiej, wywodzący się z elity księżowskiej Fedir Zarewycz (1835-1879). W powieści Chłopskie dziecko (Хлопська дитина, 1862) ${ }^{28}$ przedstawił losy chłopa Stefana Wasyłyszyna, sieroty wychowanego na plebanii greckokatolickiego proboszcza Jewstachija. Dzięki finansowemu wsparciu rodziny duchownego pokonuje on szczeble emancypacji społecznej i intymnego wtajemniczenia: szkoła, studia, kariera adwokacka, miłość i ślub z przybraną córką proboszcza - Hanią. W tym samym czasie, gdy chłopski protagonista przezwycięża ograniczenia społeczno-obyczajowe, ksiądz Jewstachij długo zachowuje wierność zasadzie nieprzekraczalności bariery między domeną chłopską a księżowską. Sojusznikiem konserwatysty pozostaje szlachcic - miejscowy dworski mandator, który uderza w konkury do popadianki, na co duchowny spogląda przychylnym okiem w imię wyznawanej przez siebie zasady: „Niech równy z równym się brata"29. Ten społeczny i patriarchalny kolaboracjonizm ${ }^{30}$ księdza Jewstachija to główny przedmiot krytyki w ramach narracji Zarewycza. Natomiast wcieleniem idealnego modelu społeczno-etnicznego jest emancypowany przez elitę ukrainofilską i emancypujący się Stefan ${ }^{31}$, który - zdobywszy najpierw wysoki status społeczny i ekonomiczny - poślubia popadiankę Hanię jak „równy z równą”.

Narracje staroruskie i ukrainofilskie w różny sposób reprezentowały intymno- społeczną transgresję chłopa. W powieściach Chylaka i Kałytowskiego już samo wydarzenie się małżeństwa z popadianką jest drogą do jego awansu - pojmowanego jako ingerencja księdza w niezmienny system

28 Ю.В. [Ф. Заревич] Хлопська дитина, „Вечорниць” 1862 № 1-18.

Tamże, № 10, s. 75 .

Nawiązuję do zjawiska nazwanego przez Spivak „patriarchalną kolaboracją” między przedstawicielami elit kolonizatorskich i skolonizowanych, które łączy taki sam stosunek do kobiety jako obiektu walki o wpływy własnego dyskursu patriarchalnego (Ґ. Чакраворті Співак Вступне слово до українського читача, w: tejżе В інших світах: есеї з питань культурної політики, пер. Р. Ткачук, І. Супрунець, А. Кулаков, Видавництво „Всесвіт”, Київ 2006, s. 23). Wystarczy wspomnieć powieść Jana Zachariasiewicza (1823-1906) Jarema (1863), w której po zniesieniu pańszczyzny postać wolnego chłopa ruskiego przedzierzga się w oczach dworu w "ucznia szkoły, z której wyszedł Szela i towarzysze [...]" (J. Zacharyasiewicz Jarema, w: tegoż Wybór pism Jana Zacharyasiewicza, t. 11, Gebethner i Wolff, Warszawa 1888, s. 157). 
pańszczyźniany, a nie wynik przemyślanej strategii upodmiotowienia chłopa. Natomiast u Zarewycza to motywowana społecznie zniesieniem pańszczyzny i wspierana przez postępową elitę emancypacja doprowadza do jego małżeństwa z popadianką. Stąd też przedstawiciel kolejnej generacji inteligencji ukrainofilskiej, Iwan Franko (1856-1916), nazwał Chłopskie dziecko pierwszą literacką przemianą ruskiego chłopa w niezależnego inteligenta ${ }^{32}$. Choć gdy przyjrzeć się dokładniej reprezentacji protagonisty, można tę jednoznaczną ocenę Franki podać w wątpliwość. Zastrzeżenie budzi znaczący szczegół: Stefan Wasyłyszyn nie zamienia swego chłopskiego odzienia nawet po zdobyciu dyplomu doktora prawa. Siermięga na chłopie-inteligencie świadczy o ambiwalentnych przekonaniach Zarewycza względem emancypacji chłopów. Pisarz w imieniu elity, nie negując, lecz negocjując różnicę między „, chłopem a popem", wpisuje go w konstruowaną wspólnotę ruską. Literacka siermięga jest metonimią zreformowanej, ale ciągle rozpoznawalnej chłopskości konstytuującej podmiotowość przedstawiciela elity ukrainofilskiej3.

\section{Życie seksualne ruskiej chłopki}

„Dla obdarzenia proletariatu ciałem i seksualnością, dla postawienia problemu jego zdrowia, płci i rozmnażania potrzebne były konflikty"34 - Foucaultowska zależność przełożona na realia agrarnej Galicji pozwala uznać chłopstwo za jej centralną figurę. W interesującym mnie okresie konfliktogenne obdarzanie chłopa ciałem i seksualnością znalazło ujście w procesach sądowych nad ukraińskimi socjalistami (1877-1878), a następnie nad czołowymi przedstawicielami elity rusofilskiej (1882). Wyroki drugiej rozprawy nieodwracalnie osłabiły Rusinów konserwatystów, wzmacniając jednocześnie ukrainofilów i tym samym aktywizując trwającą od lat 6o. transformację narodowego ruchu rusko-ukraińskiego. Zmiany te inicjowały przejście dyskursu ruskiego od cerkiewnego nadzorowania prawdy o seksualności do tworzenia podstaw laickiej, ukraińskiej scientia sexualis. W związku z brakiem

32 І. Франко Нарис історії українсько-руської літератури до 1890 р., w: tegoż Зібрання творів у п’ятдесяти томах, т. 41, Наукова думка, Київ 1984, s. 317.

Przekładam tu postkolonialne rozpoznania Homiego Bhabhy na galicyjskie stosunki społeczne - Wasyłyszyn to wcielenie projektu elity ukrainofilskiej „zreformowanego i rozpoznawalnego" chłopa, który „jest prawie taki sam, ale nie całkiem": (H.K. Bhabha Miejsca kultury, przeł. T. Dobrogoszcz, Wydawnictwo UJ, Kraków 2010, s. 79-88). 
własnej państwowości i niezależnej struktury instytucjonalnej główną rolę w wypracowywaniu ukraińskiego aparatu dyscyplinującego seksualność wzięły na siebie literatura, językoznawstwo i etnografia ${ }^{35}$. W ich ramach wynajdywano i nazywano chłopską seksualność, co wiązało się z tworzeniem literackiej ukraińszczyzny na podstawie dialektów ludowych, w tym podziału leksyki dotyczącej płciowości na normatywną i nienormatywną ${ }^{36}$. Dla ukrainofilów o poglądach socjalistycznych seksualność chłopska stawała się również wyobrażoną sferą swobody i sprzeciwu wobec galicyjskiej zachowawczości. Tak traktowali ją podsądni we wspomnianym wcześniej procesie nad socjalistami pisarze Mychajło Pawłyk (1853-1915) i Iwan Franko. Obydwaj w drugiej połowie lat 70. przeszli transformację światopoglądową od konserwatywnego rusofilstwa do socjalizmu i ukraińskiej idei narodowej ${ }^{37}$. Źródeł zainteresowań ukraińskich literatów ludową seksualnością należy szukać właśnie w okresie krystalizowania się ich poglądów, których przyszło im bronić w galicyjskim sądzie. Rozprawa ta miała również wątek literacki.

Treść oskarżenia pod adresem Pawłyka - inteligenta chłopskiego pochodzenia - sformułowano, powołując się m.in. na jego opowiadanie Rebenszczukowa Tetiana (Ребенщукова Тетяна, 1878) ${ }^{38}$.Zarzucono mu „[w]yrugowanie wiary w Boga i wszelkiej religii, usunięcie małżeństwa, a w miejsce takowego wprowadzenie gorszącego i wyuzdanego wolnolubstwa"39. Obwinienie padało nie tylko ze strony organów władzy, lecz także konserwatywnej elity ruskiej. Sam Pawłyk bronił się, utrzymując, że zainspirował się wydarzeniami i dialogami zasłyszanymi w rodzinnej wsi na Huculszczyźnie. Zarzuty, że wystąpił przeciw tradycyjnej moralności, kreując postaci chłopek, które

Pod koniec XIX wieku komisja folklorystyczna działająca przy ukraińskim Towarzystwie Naukowym im. Tarasa Szewczenki we Lwowie zaczęła zbierać folklor obsceniczny we wschodniej Galicji. Projekt ten był inspirowany działalnością naukową Fedira Wowka (1847-1918), antropologa z Ukrainy naddnieprzańskiej (М. Маєрчик „Еротичний фольклор” як дискурсивна категорія, w: Криптадії Федора Вовка: винайдення сороміцького. Етнографія сексуальности на межі XIX-XX століть, ред. М. Маєрчик, О. Боряк, Критика, Київ 2018, S. 1-51).

Por. tamże, s. 4-5, 14 .

Ukraińscy socjaliści w mniejszym lub większym stopniu z ideami socjalistycznymi łączyli poglądy narodowe (por. J. Hrycak Prorok we własnym kraju. Iwan Franko i jego Ukraina (1856-1886), przeł. A. Korzeniowska-Bihun, A. Wylegała, Wydawnictwo Krytyki Politycznej, Warszawa 2010, s. 240).

М. Павлик Ребенщукова Тетяна, передмова К. Трильовський, Чорногора, Відень [1921]. 
- zmuszane przez rodziców do poślubiania niekochanych mężczyzn - zaspokajają potrzebę miłości, również cielesnej, poza małżeństwem, odpierał argumentami zaczerpniętymi z Poddaństwa kobiet Johna Stuarta Milla, iż nic tak nie upadla kobiety, jak zmuszanie jej do stosunku płciowego bez miłości ${ }^{40}$. Dlatego jego bohaterki - poddane władzy patriarchatu i Cerkwi - pragną „wolnej miłości”, rozumianej też jako prawo do nieskrępowanego wyboru partnera seksualnego, wolnego od decydujących dla rodziców uwarunkowań majątkowych. Dla konserwatywnej części społeczeństwa była to literacka rebelia. Narracja Pawłyka przekraczała wyznaczane przez porządek patriarchalny i religijny terytorium seksualności, które stanowiła rodzina jako jedyna usankcjonowana instytucja "nasycona seksem"41.

Pawłyk, krytykując podrzędną rolę chłopki w małżeństwie oraz brak przyzwolenia Cerkwi na rozwody, głosił jednocześnie ideę związków opartych na równoprawnych stosunkach i wzajemnej miłości ${ }^{42}$. Idea ta zapewne nie mogłaby zaistnieć w ukraińskim dyskursie i literaturze, gdyby wcześniej literaci ruscy - Zarewycz czy Chyłak - nie dopuścili do swych miłosnych opowieści chłopskich bohaterek i bohaterów, gdyby nie snuli narracji o chłopsko-księżowskiej wspólnocie i gdyby tacy jak Pawłyk, czyli inteligenci o chłopskim rodowodzie, nie uwierzyli ich obietnicy udziału w miłości, rodzinie i ruskiej wspólnocie. Zawarte w powieściach Zarewycza i Chylaka wątki małżeństwa chłopa z popadianką inicjowały refleksję na temat możliwych przeobrażeń w strukturze społecznej Rusinów i w swoim czasie były nie mniej emancypacyjne niż idea „wolnej miłości”. W tym kontekście podjęta przez ukraińskiego socjalistę Pawłyka krytyka opresyjności ruskiej kultury patriarchalnej - tej samej kultury, która wcześniej współtworzyła warunki jego emancypacji - jest rezultatem przemiany chłopskości z obiektu pożądanego przez elitę w nowoczesny podmiot polityczny zdolny do autorefleksji i reprezentowania swych pragnień. Skoro konstytuowanie się podmiotu, zgodnie z ujęciem Judith Butler, jest stawaniem „przeciwko sobie, by - paradoksalnie - być dla siebie" ${ }^{\prime 3}$, to conditio sine qua non nabywania podmiotowości przez chłopa

40 Tamże, s. 55.

41 M. Rogowska-Stangret Ciało - poza Innościq i Tożsamościq̨. Trzy figury ciała w filozofii współczesnej, Fundacja Terytoria Książki, Gdańsk 2016, s. 146-147; por. również M. Foucault Historia seksualności, s. 97.

42 J. Hrycak Prorok we własnym kraju, s. 319.

43 J. Butler Psychiczne życie władzy. Teorie ujarzmienia, przeł. T. Kaszubski, Wydawnictwo Krytyki Politycznej, Warszawa 2018, s. 31, 97. 
(również Pawłyka) było przeorientowanie ruskiego dyskursu, który go powołał do bycia, w socjalistyczny dyskurs sprzeciwu.

\section{Odnamiętnianie inteligenta}

Zapoczątkowana przez Pawłyka refleksja nad „wolną miłością” pozostawała w sferze nieosiągalnej idei. W dyskursie socjalistów właśnie ta niedostępność służyła wyakcentowaniu realnych problemów nierówności społecznej i płciowej. W ten sposób autorzy przenosili do literatury poglądy spiritus movens galicyjskiej transformacji ukrainofilskiej - Mychajły Drahomanowa (1841-1895).Zdaniem wywodzącego się z Ukrainy naddnieprzańskiej czołowego ukraińskiego myśliciela socjalistycznego warunkiem wstępnym emancypacji najniższych warstw jest postęp społeczny, ekonomiczny i kulturowy, a nie frazeologia romantycznej ludowości, która zamyka się w odkrywaniu własnych wyobrażeń o wyidealizowanych chłopach, co jest przeciwskuteczne dla ich uświadomienia ${ }^{44}$. Stąd w powieściach Franki - zwolennika poglądów Drahomanowa - nieobecne są wątki miłosne z udziałem chłopów. Ich związki seksualne i małżeńskie nie mogą zaistnieć, dopóki społeczeństwo tkwi w nierównościach społecznych i ekonomicznych, w ramach których miłość i małżeństwo są skazane na reprodukowanie dominacji i podrzędności, a tym samym przemocy ${ }^{45}$.

Lejtmotywem w powieściach Franki jest natomiast dążenie do ujarzmiania namiętności przez protagonistę - najczęściej inteligenta o rodowodzie chłopskim $^{46}$. Proces ten odbywa się na drodze jego relacji z Polką, wcieleniem

М.П. Драгоманов Антракт з історії українофільства (1863-1872), w: tegoż вибране („... мій задум зложити очерк історії цивілізації на Україні"), ред. та передмова Р.С. Міщук, Либідь, Київ 1991, httр://litopys.org.ua/drag/drago8.htm (30.07.2019).

45 W podobnym duchu jeszcze na początku XX wieku edukowała seksualnie ukrainofilów naddnieprzańska pedagożka i emancypantka Sofija Rusowa (1856-1940). W artykule opublikowanym we lwowskim „Literaturno-Naukowym Wistnyku” konstatowała, że inteligencja pracująca na rzecz uświadomienia społeczno-narodowego chłopów najpierw powinna "wyjaśnić sobie własny stosunek do kobiety wiejskiej i Boże broń nasze wsie od takich nauczycieli-ludowców, którzy pojednanie z ludem zaczynają od romantycznego związku z pierwszą napotkaną ładniutką dziewczyną" (С. Русова Народник в українській літературі, „Літературно-Науковий Вісник" 1902 т. 17 ч. 2, s. 90).

Postaci te można uznać za porte-parole pisarza. Przy okazji warto zaznaczyć, że Franko - syn zamożnego wiejskiego rzemieślnika, potomka zrutenizowanych kolonistów niemieckich oraz drobnej szlachcianki z rusko-polskiego rodu Kulczyckich - sam skonstruował swoją chłopską i ukraińską tożsamość. Zewnętrznym potwierdzeniem jego wyborów tożsamościowych była 
kobiety fatalnej, która zniewala męską i ruską tożsamość bohatera. Dla Frankowskich bohaterów spotkanie z Polką jest zmierzeniem się z własną podrzędnością narodową, by następnie przełamać ją przez zapanowanie nad swą seksualnością, zdobyć władzę nad swym ciałem i uzyskać sprawczość polityczną ${ }^{47}$. Podobną rolę odgrywa spotkanie ruskiego gimnazjalisty, chłopskiego syna Borysa Hraba ze szlachcianką Michońską w powieści Nie pytając o bród (Hе спитавmu бродy, lata 80. XIX wieku) ${ }^{48}$. Epatująca zmysłowością bohaterka zniewala protagonistę. Inicjacja seksualna ze szlachcianką kończy się jego psychicznym „rozbiciem, stłamszeniem, poczuciem głębokiego wstydu" ${ }^{\text {"49 }}$. Współżycie Rusina ze szlachcianką nie przekracza, lecz penetruje ówczesne galicyjskie granice społeczne i kulturowe. Okazuje się, że taki seks wprawdzie jest możliwy, ale wynegocjowanie w jego ramach parytetu społeczno-narodowego już nie, ze względu na wpisaną weń władzę.

Dzięki ujarzmieniu seksualności jednostka panuje nad sobą, a także nad innymi - panowanie nad pragnieniami seksualnymi wyznacza bowiem sferę relacji społecznych ${ }^{50}$. Dlatego Hrab, by zdobyć podobną sprawczość, odseparowuje się od Michońskiej. Odejście to, rzutowane na relacje społeczno-narodowe w Galicji, symbolizuje ruską separację od polskości, by zyskać władzę nad reprezentacją samych siebie jako innych. Ujarzmienie seksualności przez Hraba ma zatem w sobie energię emancypacyjną: gdy zapanuje nad swymi pragnieniami zgodnie z normami dyskursu władzy, stanie się jego pełnowartościowym uczestnikiem, świadomym zarówno swego chłopskiego rodowodu, jak i podmiotowości.

\section{Chłopski sex appeal}

Elity ruskie/ukraińskie w Galicji w latach 6o.-80. XIX wieku wykorzystywały motywy miłosne i seksualne jako jedne z narzędzi konstruowania własnej tożsamości i pozycji społecznej oraz formowania nowoczesnej

zamiana miejskiego fraka na wiejską wyszywaną koszulę - symbol ukraińskiej narodowości mającej źródła w kulturze chłopskiej (por. ). Hrycak Prorok we własnym kraju, s. 44-53, 180).

47 Model ten jest obecny m.in. w powieściach Petrijowie i Dowbuszczukowie (Петрії і Довбущуки, 1876) і Rozstaje drogi (Перехресні стежки, 1900).

48 І. Франко Не спитавщи броду, w: tegoż Зібрання творів у п’ятдесяти томах, т. 18, Наукова думка, Київ 1978, s. 325-463.

49 Tamże, s. 343. M. Rogowska-Stangret Ciało - poza Innościq̨ i Tożsamościq̨, s. 193-194. 
podmiotowości Rusinów/Ukraińców. Momentem przełomowym było zaistnienie literackiej reprezentacji chłopa w roli uczestnika przestrzeni intymnej i politycznej, którego następnie elity te przedstawiały w postaci jedynego fundamentu kultury i narodu, wypierając własną rolę w konstruowaniu nowoczesnej wspólnoty. „My, Rusini, szczególnie w Galicji, od dawien dawna byliśmy narodem chłopskim"51 - pisał Franko w 1898 roku. Inteligencja ruska/ukraińska, formując chłopski mit założycielski, walczyła o władzę nad reprezentacjami samych siebie i „,swego" chłopstwa ze szlachtą polską, chcącą utrzymać własny dominujący dyskurs o mieszkańcach byłej Rzeczypospolitej. Paradoksem tej walki było to, że wyobrażony przez inteligencję ruską/ ukraińską "naród chłopski” odpowiadał stereotypowi szlachty o ruskości jako żywiole wyłącznie chłopskim, w naturalny sposób jej podległym. Doszło tu do znamiennej różnicy: elity polskie kulturę narodową sprowadziły do kultury szlacheckiej, natomiast elity ruskie/ukraińskie wynalezioną przez siebie kulturę chłopską ustanowiły w roli kultury narodowej. Myślenie o narodzie ukraińskim zredukowanym do chłopskości odniosło taki sukces, że do dziś jej sex appeal sprawuje władzę nad reprezentacją przeszłości i teraźniejszości Ukraińców w kulturze i społeczeństwie polskim oraz ukraińskim ${ }^{52}$. Wywiera również wpływ na część badaczy niepodejmujących pogłębionej refleksji nad procesem konstruowania tego mitu, tak jakby za nim nie stali ojcowie założyciele należący do ruskich elit. W tym kontekście warto zadać pytanie, czy współczesny chłopski zwrot humanistyki polskiej, weryfikujący szlachecką wizję narodu polskiego, zdoła zdekonstruować szlacheckie wyobrażenie chłopskiego narodu ukraińskiego?

51 І. Франко Панщина та її скасування 1848 р. в Галичині, w: tegoż зібрання творів у п'ятдесяти момах, т. 47, Наукова думка, Київ 1986, s. 108. skiego Zniewolona (KpinocHa) o losach wychowanej we dworze małoruskiej chłopki pańszczyźnianej. Por. K. Mróz Brazylijska miłość, ukraińskie batożenie. Czy „Zniewolona” to fenomen na miarę "Niewolnicy Isaury"?, "Gazeta Wyborcza”, 1.08.2019, http://wyborcza.pl/7,90535,25048953,brazylijska-milosc-ukrainskie-batozenie-czy-zniewolona-to.html (2.08.2019). 


\section{Abstract}

\section{Katarzyna Glinianowicz}

THE INSTITUTE OF SLAVIC STUDIES, POLISH ACADEMY OF SCIENCES

Can Ruthenian Peasants Be Sexy? How the Elite Deployed Sexuality in Galicia

In her critical reflection on Polish subaltern studies on Polish-Ukrainian relations Glinianowicz draws attention to the Ruthenian/Ukrainian comprador elites who competed with the Polish nobility for knowledge/power over the Ruthenian peasantry. She then analyses the portrayal of peasants in prose by representatives of these elites in Galicia from the 1860 s to the 1880 s. Drawing on Foucault's theory of sexuality Glinianowicz examines the peasantry's emancipation and their inclusion by the Ruthenian/Ukrainian elites into the intimate and political space of society. The paper reveals the elites' decisive role in constructing modern Ukrainian identity, the ideological game of peasant sexuality, and it also deconstructs the foundations of the enduing stereotype of the rustic character of Ukrainian culture.

\section{Keywords}

Ruthenian/Ukrainian elites, peasants, Polish nobility, sexuality, emancipation, Galicia 